\title{
Psikiyatri Kliniğinde Yatan Hastaların Bakım Gereksinimleri ve Özsaygı Düzeylerinin İncelenmesi
}

\section{Investigation of Care Requirements and Self-Esteem Levels of Patients Hospitalized in the Psychiatry Clinic}

\author{
Ceyda Başoğul ${ }^{1 *}$, Aysun Kalenderoğlu ${ }^{2}$ \\ ${ }^{1}$ Adıyaman Üniversitesi Sağlık Bilimleri Fakültesi, Psikiyatri Hemşireliği Anabilim Dalı, Adıyaman, Türkiye \\ ${ }^{2}$ Adıyaman Üniversitesi, Tıp Fakültesi, Psikiyatri Anabilim Dalı, Adıyaman, Türkiye \\ e-mail: ceydayk@hotmail.com, ilhan_aysun@yahoo.com \\ ORCID: 0000-0001-7290-9123 \\ ORCID: 0000-0002-8216-8610 \\ *Sorumlu yazar/ Corresponding Author: Ceyda Başoğul \\ Gönderim Tarihi / Received: 05.11.2020 \\ Kabul Tarihi / Accepted: 06.04.2021 \\ DOI: $10.34087 /$ cbusbed. 822039
}

Giriş ve Amaç: Çalışmanın amacı, psikiyatri kliniğinde tedavi gören hastaların bakım gereksinimleri ve özsaygı düzeylerinin incelenmesidir.

Gereç ve Yöntemler: Kesitsel ve tanımlayıcı desene sahip çalışmaya 81 hasta dâhil edildi. Araștırma verileri kişisel bilgi formu, Rosenberg Özsaygı Ölçeği ve Bakım Gereksinimleri Belirleme Formu ile toplandı. Verilerin çözümlenmesinde tanımlayıcı istatistikler, tek yönlü ANOVA, bağımsız örneklem $t$ testi ve çoklu regresyon analizi kullanıldı.

Bulgular: Bireylerin \%45,7'sinin özsaygı düzeyinin düşük, \%32,1'inin orta olduğu belirlendi. Ayrıca bireylerin özsaygı düzeyinin sağlık yönetimi, benlik kavramı, kendine bakım, fizyolojik fonksiyonlar, manevi boyut, rol ve ilişkiler ile başetme alanlarındaki bakım gereksinimlerine göre anlamlı farklılık gösterdiği bulundu. Ayrıca "çalışma durumu, genel görünüm, yorgunluk şiddeti, intihar riski ve beğenilen özellikler” değişkenleri özsaygı puanlarının anlamlı yordayıcılarıdır $\left(\mathrm{R}^{2}=0,53, p<0,01\right)$.

Sonuç: Psikiyatri kliniğinde tedavi gören hastaların yaklaşık yarısının özsaygı düzeyi düşüktü ve birçok alandaki bakım gereksinimleri özsaygı düzeyi ile ilişkili bulundu. Bireylerin özsaygı düzeylerini yükseltmek için planlanan hemşirelik girişimlerinde hastaların ilişkili gereksinim alanlarının özellikle değerlendirilmesi önerilmektedir.

Anahtar kelimeler: Bakım, Gereksinim, Psikiyatri hastaları, Özsaygı.

\footnotetext{
Abstract

Objective: This study was conducted to investigate the care requirements and self-esteem levels of patients hospitalized in the psychiatry clinic.

Material and Methods: 81 patients were included in the study with a cross-sectional and descriptive pattern. The research data were collected by personal information form, Rosenberg Self-Esteem Scale and Care Requirements Determination Form. Descriptive statistics, one-way ANOVA, independent sample t-test and multiple regression analysis were used to analyze the data.

Results: $45.7 \%$ of the individuals have low self-esteem level, $32.1 \%$ are moderate; self-esteem levels were found to differ significantly in terms of care requirements in the areas of health management, self-concept, self-care, physiological functions, spiritual dimension, role and relationships, and coping. Besides, the variables of "working status, general appearance, fatigue severity, suicide risk, admirable features" are significant predictors of self-esteem scores $\left(\mathrm{R}^{2}=0.53, p<0.01\right)$

ConclusionAbout half of the patients treated in the psychiatric clinic had low self-esteem and care requirements in many areas were associated with their self-esteem. In nursing interventions planned to increase the self-esteem levels of individuals, it is recommended that patients' related requirements are particularly evaluated.
} 
Keywords: Care requirements, Psychiatric patients, Self-esteem.

\begin{abstract}
1. Giriş
Dünyada, son yllarda yaşanan demografik değişim, devletlerarası çatı̧̧malar, yoksulluk, doğal afetler ve salgın hastalıklar sonucu ruhsal bozukluklar giderek yaygınlaşmaktadır. Bunun yanında ruhsal bozukluğu olan bireyler ülkelerin çoğunda herhangi bir bakım hizmetinden yararlanamamaktadır [1]. Evrensel ruh sağllğı hizmetlerinin iyileştirilmesi hedefi temelinde, ruhsal hastalığ belirlemek ve bu doğrultuda bakım ve hizmet kalitesini artırmak önemlidir.
\end{abstract}

Ruhsal bozukluğu olan bireylerin gereksinimleri; fiziksel ve psikososyal kayıpların yaşanmasına bağlı olarak bakım, destek ve yeterli hizmet ihtiyacını ifade etmektedir [2]. Uygun bakım biçimlerine erişim eksikliğini yansıtan gereksinimlerin değerlendirilmesi, klinik psikiyatride hem hizmetlerin hem de tedavinin planlanmasında gerekli olmakla birlikte teşhis, işlevsellik ve alınan bakımın değerlendirilmesini sağlar [3]. Taş ve Buldukoğlu (2018) çalışmalarında şizofreni hastalarının taburculuğun erken döneminde bakım gereksinimlerini değerlendirmişler ve hastaların taburculuktan sonra kendine bakım, benlik kavramı, tedavi ve bakım, uyku, başetme, rol ve ilişkiler, manevi boyut, güvenli çevre ve bilgi gereksinimi alanlarından en az birinde bakım gereksinimlerinin olduğunu belirtmişlerdir [4]. Kronik ruhsal bozukluğu olan bireylerin gereksinimlerini belirlemeye yönelik yapılan çalışmaları inceleyen bir sistematik derlemede (2020); hastaların sosyal ve yakın ilişkiler, fiziksel sağlık durumu, gündüz aktiviteleri, psikolojik sıkıntı, sosyal yardım ücreti, ulaşım, hastalık süreci ve tedavisi hakkında bilgi, başkalarının güvenliği, cinsel yaşam, uyku alanlarında gereksinimlerinin olduğu ve bu gereksinimlerin karşıllanmamış olduğu saptanmıştır [2]. Ruhsal hastalığı olan bireylerin birçok alanda gereksinimlerini karşılamada yaşadıkları güçlükler, kendilerini sorgulamaya, yetersizlik hissetmeye ve özsaygıda azalmaya neden olabilir. Bu bakış açısıyla, bireylerin gereksinim alanları ve bu karşılanmamış gereksinimlerin bireylerin özsaygı düzeyine etkisinin incelenmesi önem kazanmaktadır.

Ruhsal hastalıklarda özsaygı düzeyindeki değişiklikler birçok açıdan irdelenmiş ve anlaşılmaya çalışılmıştır [5]. Özsayg1 (benlik saygısı), kişinin bir insan olarak değerinin genel bir değerlendirmesidir [6]. Başka bir tanımla; bireyin öz değerlendirme ile ulaştığı benlik kavramının onaylamasından doğan beğeni durumudur [7]. Bazı araştırmacılar, psikiyatrik hastalıkların kişinin özsaygısını azalttığını öne sürmektedirler; psikiyatrik hastalıkların bașetme mekanizmalarını, karar verme becerilerini ve problem çözme yeteneklerini kısıtlaması nedeniyle değerlilik hissi ve özsaygı azalabilir [8]. Bir ruhsal hastalık nedeniyle hastaneye yatırılan kişiler reddedilme endişesiyle kendilerini daha az güvende hissedebilir, daha savunmacı bir şekilde hareket edebilir veya tamamen temastan kaçınabilirler. Sosyal etkileşimin ve ağların kısıtlanması, damgalanma, işsizlik ve gelir kaybı, işlevselliğin azalması gibi sonuçlarla karşılaşılabilir. Bu olumsuz etkilerle birlikte bireylerin özsaygıları da etkilenebilir. Çünkü bireyler diğerlerinden daha az yetenekli ve daha az değerli oldukları sonucuna varabilirler [9]. Bazı araştırmacılar düşük özsaygının bireyleri psikiyatrik hastalıklara karşı savunmasız hale getirdiğini ileri sürmektedirler [10]. Diğer bir deyişle, olumlu özsaygı, insanları ruhsal hastalıkların olumsuz etkilerinden koruyabilir ve etkili başa çımayı kolaylaştırır. Böylece özsaygı, ruh sağlığında koruyucu bir faktör olarak hareket eder [7]. Bazı araştırmacılar ise; düşük özsaygı ile psikiyatrik hastalıklar arasında kısır bir döngü olduğunu ileri sürmektedir [11]. Yapılan çalışmalarda bazı hastalıklarda daha düşük olmakla (şizofreni, majör depresyon, obsesif kompulsif bozukluk, yeme bozukluğu, madde kullanım bozukluğu) birlikte, psikiyatrik bozukluğu olan hastaların özsaygı düzeylerinin bazı derecelerde düşük olduğu belirtilmektedir $[8,12]$. Ayrıca, hastalığın başlangıcında özsaygı düzeyinin daha yüksek olması ile daha olumlu tedavi sonuçlarının önemli ölçüde ilişkili olduğunu gösteren kanıtlar vardır [13]. Sonuç olarak; ruhsal hastalıklarda özsaygı önemle üzerinde çalışılması ve ruh sağlığ $\breve{1}_{1}$ profesyonelleri tarafından hastaların desteklenmesi gereken bir konudur.

Literatürde, psikiyatri hastalarının özsaygı düzeylerini $[8,11,12]$ ve bazı alanlardaki gereksinimlerini inceleyen çalışmalar bulunmaktadır [2,4]. Ancak psikiyatri kliniğinde yatarak tedavi gören psikiyatri hastalarının bakım gereksinimlerini kapsamlı bir şekilde inceleyen ayrıca özsaygı düzeylerini hastaların gereksinimleri bağlamında inceleyen bir çalışmaya ulaşılamamıștır. Özsaygının duygu, düşünce ve davranışlar temelinde birçok açıdan bireyleri etkilediği düşünüldüğünde hemşirelik bakımının planlanmasında özenle ele alınması önem taşımaktadır. Psikiyatri hastalarında özsaygının incelenmesinin, sağlık profesyonellerinin bu konuda farkındalığının artmasına ve bakım kalitesinin iyileştirilmesine katk1 sunacağ1 düşünülmektedir. $\mathrm{Bu}$ nedenle, bu araştırma psikiyatri kliniğinde yatan hastaların özsaygı düzeyleri ve bakım gereksinimleri arasındaki ilişkiyi incelemek amacıyla yapılmıştır. Araștırmada yanıt aranan sorular:

Psikiyatri kliniğinde yatarak tedavi gören bireylerin;

- $\quad$ özsaygıları hangi düzeydedir?

- bakım gereksinimleri nelerdir?

- $\quad$ özsaygı puanları sosyodemografik ve bakım gereksinimleri değişkenlerinden nasıl etkilenmektedir?

\section{Materyal ve Metot}

\subsection{Araştırmanın Tasarımı}

Araştırma psikiyatri kliniğinde yatan hastaların özsaygı düzeyleri ve bakım gereksinimleri arasındaki ilişkiyi incelemek amaciyla kesitsel ve tanımlayıcı tipte tasarlandi.

\subsection{Araştırmanın Yeri ve Zamanı}

Araştırma, Türkiye'nin güneydoğusunda bir eğitim araştırma hastanesi psikiyatri kliniğinde Ocak-Haziran 2020 tarihleri arasında yürütüldü.

2.3. Araştırmanın Evreni ve Örneklemi 
Araştırmanın evrenini Türkiye'nin güneydoğusunda bir eğitim araştırma hastanesi psikiyatri kliniğinde yatarak tedavi gören hastalar oluşturdu. Ocak-Haziran 2020 tarihleri arasında kliniğe 149 hastanın yatışı yapıldı. Araştırmaya dâhil edilme kriterleri; minimum 1 yıldır psikiyatrik tanı alma, çalışmanın amacını anlama ve çalışmaya katılmayı kabul etme, 18-70 yaş arasında olmadır. Dışlanma kriterleri ise; bunama ya da genel tıbbi duruma bağlı bir psikiyatrik bozukluğun olması, zekâ geriliği ve iletişim sorununun bulunmasıdır. Örneklem seçimine gidilmeyip dahil edilme kriterlerine uyan ve çalışmaya katılmayı kabul eden tüm bireyler araştırma kapsamına alındı. Sonuç olarak araştırma 81 bireyle tamamlandi.

\subsection{Veri Toplama Araçları}

Araştırmada verilerin toplanması amacıyla 3 form kullanild1.

2.4.1. Kişisel Bilgi Formu; araştırmacılar tarafından literatüre dayalı olarak geliştirilen bu form, katılımcıların yaş, cinsiyet, eğitim, medeni durum, birlikte yaşadığ kişiler, çalışma durumu, ekonomik durumu ve psikiyatrik tanısı ile ilgili olmak üzere 7 soru içermektedir.

2.4.2. Bakım Gereksinimleri Belirleme Formu; araştırmacılar tarafından literatüre dayalı olarak hazırlandı $[2,4,14,27]$. Gereksinimleri belirlemek için 7 temel ve alt alanlar belirlendi. Bu alanlar; sağlık yönetimi (genel sağlığı değerlendirme, tedaviye uyum, sağlık bakımına karar verme, intihar riski); benlik kavramı (kendini tanımlama, beğendiği özellikler, değiştirmek istediği özellikler); kendine bakım (günlük bakımını yapabilme, genel görünüm); fizyolojik fonksiyonlar (beslenme, boşaltım, cinsel yaşam, uyku); manevi boyut (yaşam ve ölümle ilgili inançlarda etkilenme); rol ve ilişkiler (eğitim ve çalışma yaşamında, aile içi ve sosyal ilişkilerde etkilenme); başetme (yaşamında stres yaratan olay varlığ 1 , kullanılan başetme yöntemleri, sosyal destek yeterliği) dir. Bu alanların değerlendirilmesinde açı ve kapalı uçlu olmak üzere toplam 27 soru ve gözlem yöntemi kullanıldı. Form içeriği oluşturulurken alana özgü soruların yer almasına özen gösterildi (intihar riski, bireylerin beğendiği, değiştirmek istediği özellikler, stres yaratan olayın varlığı gibi). Ayrıca yorgunluk şiddetini değerlendirmede skala kullanımı ve beden kitle indeksini hesaplama gibi yöntemler kullanıldı. Yanıtlara göre bireylerin bakım gereksinimlerinin belirlenmesini kolaylaştırıcı olması için her alana ait sorular grup şeklinde düzenlendi. Formun hazırlanma sürecinde psikiyatri hemşireliği alanında iki uzmandan görüş alındı ve önerileri doğrultusunda gerekli düzenlemeler yapılarak son hali verildi.

2.4.3. Rosenberg Özsaygı Ölçeği (RÖSÖ); Rosenberg (1965) tarafından geliştirilen ölçek kişinin özsaygısının genel bir değerlendirmesini sağlar. Dörtlü likert türünde (çok doğru, doğru, yanlış, çok yanlış) olan ölçek Guttman değerlendirme yöntemiyle puanlanan 10 maddeden oluşur. 1, 2, 4, 6 ve 7. ifadeler ters ifadelerdir. Değerlendirme sistemine göre 0-1 puan: yüksek; 2-4 puan: orta; 5-6 puan: düşük düzeyde özsaygı olarak değerlendirilmiştir. Puanın yükselmesi, özsaygı düzeyinin düştüğünü göstermektedir. Örnek madde ifadeleri; genelde kendimi başarısız bir kişi olarak görme eğilimindeyim, bazı olumlu özelliklerim olduğunu düşünüyorum, kendimde gurur duyacak fazla bir şey bulamıyorum gibi [6]. Türkçe' ye uyarlama çalışması Çuhadaroğlu (1986) tarafından yapılmıştır. Ölçeğin test tekrar test güvenirlik yöntemi kullanılarak hesaplanan güvenirlilik katsayısı 0,75 ve geçerlik katsayısı 0,71 olarak bulunmuştur [15]. Bu çalışmada Cronbach alfa değeri 0,68 olarak hesaplandi.

Veriler bir görüşme odasında soru formlarının doldurulması ve gözlem yöntemleri kullanılarak toplandı. Verilerin toplanması ortalama $30 \mathrm{dk}$ sürdü.

2.5.Verilerin Analizi

Verilerin değerlendirilmesinde SPSS 21.00 kullanıldı. Demografik özelliklerin ve ölçek sonuçlarının analizi için sayı, yüzde dağılım, aritmetik ortalama ve standart sapma değerleri kullanıldı. Verilerin normal dağılım özelliğini değerlendirmek için Kolmogorov-Smirnov testi uygulandıktan sonra normal dağılımlı veriler tek yönlü ANOVA ve bağımsız örneklem t testi ve çoklu regresyon analizi ile değerlendirildi, istatistiksel anlamlılık değeri $\mathrm{p}<0,05$ olarak kabul edildi.

2.6. Araştırmanın Etik Yönü

Çalışmanın yapılabilmesi için Girişimsel Olmayan Etik Kurulundan etik onay (Onay tarihi ve karar sayısı: 7 Aralık 2019-2019/9-25) ve hastane yönetiminden kurumsal izin alındı. Hasta ve varsa/gerekliyse yakınları çalışma hakkında bilgilendirildikten sonra sözlü ve yazılı onamları alındı. Veri toplamada kullanılan ölçek için kullanım izni alındı.

\section{Bulgular ve Tartışma \\ 3.1 Bulgular \\ 3.1.1. Bireylerin Tanttıcı Özellikleri}

Hastaların tanıtıcı özelliklerine göre özsaygı puan ortalamaları Tablo1'de yer almaktadır.

Katılımcıların yaş ortalaması 35,9 $\pm 13,1$ idi; \%69,1'i erkek, \%54,3'ü ilkokul mezunu, \%65,4'ü bekâr, \%50,6's1 ebeveynleriyle yaşamakta, \%90,1'i herhangi bir işte çalışmamakta, \%63'ünün ekonomik durumu orta ve \%40,7'si şizofreni tanısıyla tedavi görmektedir (Tablo 1). Bireylerin tanıtıcı özelliklerine göre özsaygı düzeyleri incelendiğinde; üniversite/lisansüstü mezunu olan bireylerin ve çalışan bireylerin özsayg1 düzeyi istatistiksel olarak anlamlı düzeyde yüksek bulunmuştur $(p=0,024 ; p=0,006)$. Bireylerin hastalık tanılarına göre özsayg1 düzeyleri değerlendirildiğinde, depresif bozukluğu olan bireylerin en düşük, bipolar bozukluğu olan bireylerin en yüksek düzeyde olduğu ve bu farkın istatistiksel olarak anlamlı olduğu bulunmuştur $(p=0,000)$. Bireylerin özsaygı puan ortalamaları arasında yaş, medeni durum, cinsiyet, yaşadığı kişiler ve ekonomik durum gibi değişkenler açısından istatistiksel olarak anlamlı bir fark bulunmamıştır (Tablo1).

\subsubsection{Bireylerin Özsaygı Düzeyleri}

Araştırma kapsamına alınan bireylerin özsaygı ölçeği toplam puan ortalaması 3,65 $\pm 2,09$ (orta düzey)'dir (Ölçek puan aralığg 0-6). Bireylerin \%45,7'sinin özsayg1 
Tablo 1. Hastaların Tanıtıcı ve Hastalık Özelliklerine Göre Özsaygı Puan Ortalamalarının Karşılaştırılması $(\mathrm{N}=81)$

\begin{tabular}{|c|c|c|c|c|}
\hline Özellikler & $\mathbf{N}$ & $\%$ & $\begin{array}{c}\text { RÖSÖ } \\
\text { X } \pm \text { SD }\end{array}$ & Analiz \\
\hline $\begin{array}{l}\text { Yaş } \\
18-24 \\
24-34 \\
35-45 \\
45-55 \\
55-u ̈ s t u ̈ ~\end{array}$ & $\begin{array}{c}16 \\
32 \\
\\
9 \\
12 \\
12\end{array}$ & $\begin{array}{l}19,8 \\
39,5 \\
11,1 \\
14,8 \\
14,8\end{array}$ & $\begin{array}{l}3,62 \pm 2,47 \\
3,03 \pm 2,13 \\
3,88 \pm 1,69 \\
4,41 \pm 1,62 \\
4,41 \pm 1,92\end{array}$ & $\begin{array}{c}\mathrm{F}=1,569 ; \\
p=0,191\end{array}$ \\
\hline $\begin{array}{l}\text { Cinsiyet } \\
\text { Kadın } \\
\text { Erkek }\end{array}$ & $\begin{array}{l}25 \\
56\end{array}$ & $\begin{array}{l}30,8 \\
69,2\end{array}$ & $\begin{array}{l}2,52 \pm 1,32 \\
2,71 \pm 1,37\end{array}$ & $\begin{array}{l}\mathrm{t}=-0,595 ; \\
p=0,554\end{array}$ \\
\hline $\begin{array}{l}\text { Eğitim } \\
\text { Okuryazar değil } \\
\text { Okuryazar } \\
\text { İlkögretim } \\
\text { Lise } \\
\text { Üniversite/lisansü } \\
\text { stü }\end{array}$ & $\begin{array}{c}5 \\
5 \\
44 \\
20 \\
7\end{array}$ & $\begin{array}{c}6,2 \\
6,2 \\
54,3 \\
24,7 \\
8,6\end{array}$ & $\begin{array}{l}5,80 \pm 0,44 \\
3,40 \pm 2,40 \\
3,81 \pm 2,10 \\
3,45 \pm 1,95 \\
1,85 \pm 1,67\end{array}$ & $\begin{array}{c}\mathrm{F}=2,995 \\
p=0,024\end{array}$ \\
\hline $\begin{array}{l}\text { Medeni durum } \\
\text { Evli } \\
\text { Bekâr }\end{array}$ & $\begin{array}{l}28 \\
53\end{array}$ & $\begin{array}{l}34,6 \\
65,4\end{array}$ & $\begin{array}{l}3,67 \pm 2,19 \\
3,64 \pm 2,06\end{array}$ & $\begin{array}{l}\mathrm{t}=0,075 \\
p=0,940\end{array}$ \\
\hline $\begin{array}{l}\text { Yaşadığı kişiler } \\
\text { Ebeveynler } \\
\text { Eş ve çocuklar } \\
\text { Kardeşler } \\
\text { Çocuklar } \\
\text { Yalnız }\end{array}$ & $\begin{array}{c}41 \\
28 \\
2 \\
3 \\
7\end{array}$ & $\begin{array}{c}50,6 \\
34,6 \\
2,5 \\
3,7 \\
8,6\end{array}$ & $\begin{array}{l}3,48 \pm 2,11 \\
3,67 \pm 2,19 \\
6,00 \pm 0,00 \\
4,66 \pm 1,52 \\
3,42 \pm 1,98\end{array}$ & $\begin{array}{l}\mathrm{F}=0,880 \\
p=0,480\end{array}$ \\
\hline $\begin{array}{l}\text { Çalışma durumu } \\
\text { Çalışıyor } \\
\text { Çalışmıyor }\end{array}$ & $\begin{array}{c}8 \\
73\end{array}$ & $\begin{array}{c}9,9 \\
90,1\end{array}$ & $\begin{array}{l}1,75 \pm 2,18 \\
3,86 \pm 1,99\end{array}$ & $\begin{array}{l}\mathrm{t}=2,818 \\
p=0,006\end{array}$ \\
\hline $\begin{array}{l}\text { Ekonomik } \\
\text { durumu } \\
\text { Kötü } \\
\text { Orta } \\
\text { İyi }\end{array}$ & $\begin{array}{c}24 \\
51 \\
6\end{array}$ & $\begin{array}{c}29,6 \\
63,0 \\
7,4\end{array}$ & $\begin{array}{l}4,25 \pm 1,67 \\
3,50 \pm 2,26 \\
2,50 \pm 1,64\end{array}$ & $\begin{array}{l}\mathrm{F}=2,048 \\
p=0,136\end{array}$ \\
\hline $\begin{array}{l}\text { Psikiyatrik Tanı } \\
\text { Şizofreni } \\
\text { Bipolar bozk, } \\
\text { Depresif bozk, } \\
\text { Anksiyete bozk, } \\
\text { Madde kul. bozk, }\end{array}$ & $\begin{array}{c}33 \\
22 \\
15 \\
8 \\
3\end{array}$ & $\begin{array}{c}40,7 \\
27,2 \\
18,5 \\
9,9 \\
3,7\end{array}$ & $\begin{array}{l}3,90 \pm 1,94 \\
2,18 \pm 2,15 \\
5,20 \pm 1,08 \\
4,00 \pm 1,51 \\
2,64 \pm 1,52\end{array}$ & $\begin{array}{c}\mathrm{F}=6,318 ; \\
p=0,000\end{array}$ \\
\hline
\end{tabular}

düzeyi düşük, \%32,1'inin orta ve $\% 22,2$ 'sinin yüksek olduğu bulunmuştur (Tablo 2).

Tablo 2. Bireylerin Özsayg1 Düzeyleri

\begin{tabular}{|l|c|c|c|c|}
\hline RÖSÖ & $\mathrm{N}$ & $\%$ & $\mathrm{X} \pm \mathrm{SD}$ & Min-Max \\
\hline 0-1 puan & 18 & 22,2 & $0,56 \pm 0,511$ & $0-6$ \\
\hline 2-4 puan & 26 & 32,1 & $3,03 \pm 0,82$ & $0-6$ \\
\hline 5-6 puan & 37 & 45,7 & $5,59 \pm 0,49$ & $0-6$ \\
\hline Toplam & 81 & 100 & $3,65 \pm 2,09$ & $0-6$ \\
\hline
\end{tabular}

RÖSÖ: Rosenberg'in Özsaygı Ölçeği
Tablo 3. Bireylerin Sağlık Yönetimi, Kendine Bakım ve Benlik Kavramı Alanlarında Bakım Gereksinimlerine Göre Özsaygı Puanları $(\mathrm{N}=81)$

\begin{tabular}{|c|c|c|c|c|}
\hline $\begin{array}{l}\text { BAKIM GEREKSINIM } \\
\text { ALANLARI }\end{array}$ & $\mathbf{N}$ & $\%$ & $\begin{array}{c}\text { RÖSÖ } \\
\mathbf{X} \pm \text { SD }\end{array}$ & Analiz \\
\hline \multicolumn{5}{|l|}{ SAĞLIK YÖNETIMİ } \\
\hline \multicolumn{5}{|l|}{$\begin{array}{l}\text { Genel sağllğı } \\
\text { değerlendirme }\end{array}$} \\
\hline İyi & 33 & 40,7 & $2,93 \pm 1,78$ & \multirow{3}{*}{$\begin{array}{c}\mathrm{F}=3,761 \\
; \\
p=0,028\end{array}$} \\
\hline Orta & 13 & 16,0 & $3,76 \pm 2,35$ & \\
\hline Kötü & 35 & 43,2 & $4,28 \pm 2,12$ & \\
\hline \multicolumn{5}{|l|}{ Tedaviye uyum } \\
\hline Evet & 62 & 76,5 & $3,61 \pm 2,04$ & \multirow{2}{*}{$\begin{array}{c}\mathrm{t}=- \\
0,319 ; \\
p=0,751\end{array}$} \\
\hline Hayır & 18 & 23,5 & $3,78 \pm 2,32$ & \\
\hline \multicolumn{5}{|l|}{$\begin{array}{l}\text { Sağlık bakımına karar } \\
\text { verme }\end{array}$} \\
\hline Kendisi & 25 & 30,9 & $2,92 \pm 2,19$ & \multirow{3}{*}{$\begin{array}{c}\mathrm{F}=2,304 \\
; \\
p=0,107\end{array}$} \\
\hline Ebeveynler & 25 & 30,9 & $4,04 \pm 1,98$ & \\
\hline Aile üyeleri & 31 & 38,3 & $3,93 \pm 2,01$ & \\
\hline \multicolumn{5}{|l|}{ İntihar riski } \\
\hline Var & 15 & 18,5 & $4,73 \pm 1,53$ & \multirow{2}{*}{$\begin{array}{l}\mathrm{t}=2,784 \\
p=0,010\end{array}$} \\
\hline Yok & 66 & 81,5 & $3,40 \pm 2,14$ & \\
\hline \multicolumn{5}{|l|}{ KENDİNE BAKIM } \\
\hline \multicolumn{5}{|l|}{$\begin{array}{l}\text { Günlük bakımınt } \\
\text { yapabilme }\end{array}$} \\
\hline Bağımsız & 54 & 66,7 & $3,07 \pm 2,06$ & \multirow{3}{*}{$\begin{array}{c}\mathrm{F}=7,301 \\
; \\
p=0,001\end{array}$} \\
\hline Denetim/yardımla & 25 & 30,9 & $4,76 \pm 1,71$ & \\
\hline Bağımlı & 2 & 2,5 & $5,50 \pm 0,70$ & \\
\hline \multicolumn{5}{|l|}{ Genel görünümm } \\
\hline Bakımlı & 50 & 61,7 & $2,94 \pm 2,07$ & \multirow{2}{*}{$\begin{array}{c}\mathrm{t}=- \\
4,574 ; \\
p=0,000\end{array}$} \\
\hline Bakımsız & 31 & 38,3 & $4,80 \pm 1,57$ & \\
\hline \multicolumn{5}{|l|}{ BENLİK KAVRAMI } \\
\hline Kendini tanımlama & & & & \multirow{4}{*}{$\begin{array}{c}\mathrm{F}=17,93 \\
; \\
p=\mathbf{0 , 0 0 0}\end{array}$} \\
\hline Olumlu & 30 & 37 & $2,66 \pm 1,86$ & \\
\hline Orta & 11 & 13,6 & $2,09 \pm 1,81$ & \\
\hline Olumsuz & 40 & 49,4 & $4,82 \pm 1,66$ & \\
\hline \multicolumn{5}{|l|}{ Beğenilen özellikler } \\
\hline Kişilik özl, & 22 & 27,2 & $3,18 \pm 2,06$ & \multirow{6}{*}{$\begin{array}{c}\mathrm{F}=2, \mathbf{4 2 6} \\
; \\
p=0,043\end{array}$} \\
\hline Fiziksel özl, & 5 & 6,2 & $2,20 \pm 1,78$ & \\
\hline İletişim özl, & 2 & 2,5 & $4,50 \pm 2,12$ & \\
\hline Zihinsel özl, & 10 & 12,3 & $3,60 \pm 2,01$ & \\
\hline Manevi özl, & 15 & 18,5 & $3,00 \pm 2,26$ & \\
\hline Yok & 27 & 33,3 & $4,62 \pm 1,84$ & \\
\hline \multicolumn{5}{|l|}{$\begin{array}{l}\text { Değiştirmek istenilen } \\
\text { özellikler }\end{array}$} \\
\hline Kişilik özl, & 7 & 8,6 & $4,28 \pm 2,21$ & \multirow{7}{*}{$\begin{array}{c}\mathrm{F}=\mathbf{4 , 4 8 8} \\
; \\
p=0,001\end{array}$} \\
\hline Fiziksel özl, & 4 & 4,9 & $4,25 \pm 1,70$ & \\
\hline İletişim özl, & 17 & 21 & $3,94 \pm 1,88$ & \\
\hline Zihinsel özl, & 1 & 1,2 & 4,00 & \\
\hline Manevi özl, & 3 & 3,7 & $3,33 \pm 2,51$ & \\
\hline Hastalıkla ilgili özl, & 36 & 44,4 & $4,22 \pm 1,83$ & \\
\hline Yok & 13 & 16 & $1,23 \pm 1,64$ & \\
\hline
\end{tabular}




\subsubsection{Sağllk Yönetimi \\ 3.1.4.Bireylerin Bakım Gereksinim Alanları ve Özsaygı Düzeyleri}

Çalışma kapsamına alınan bireylerin bakım gereksinimleri 7 temel alan ve alt alanlara göre değerlendirildi ve gereksinim alanlarına göre özsaygı düzeyleri incelendi. Sağlık yönetimi, kendine bakım ve benlik kavramı alanları Tablo 3'de, fizyolojik fonksiyonlar ve manevi boyut Tablo 4'te, rol ve ilişkiler ve bașetme alanları Tablo 5'te sunulmuştur.

Genel sağlığı değerlendirme alanında; bireylerin \%43,2'sinin genel sağlığını kötü olarak değerlendirdiği ve özsaygı düzeylerinin daha düşük olduğu bulunmuştur. Sağlığını iyi olarak değerlendirenler ile kötü olarak değerlendiren bireylerin özsaygı düzeyi arasındaki fark istatistiksel olarak anlamlıdır $(\mathrm{p}=0,028)$. Bireylerin $\% 76,5$ inin tedaviye uyumlu oldukları, \%38,3 ünün aile üyelerinin sağlık bakımına karar verdiği ve \%18,5 inin intihar riski bulunan hastalar olduğu belirlenmiştir. İntihar riski bulunan hastaların özsaygı düzeyi, intihar riski bulunmayanlardan anlamlı düzeyde daha düşük bulunmuștur ( $\mathrm{p}=0,01)$ (Tablo 3$)$.

\subsubsection{Kendine Bakım}

Bireylerin \%66,7sinin günlük bakımını bağımsız düzeyde yapabildiği ve kendi bakımını yapabilmede bağımlı olan gruba göre özsaygı düzeyinin istatistiksel olarak anlamlı düzeyde daha yüksek olduğu saptanmıştır $(\mathrm{p}=0,001)$.

Genel görünüm alt alanında hastaların \%61,7'sinin bakımlı göründüğü ve bu grubun özsaygı düzeylerinin bakımsız görünen hastalara göre istatistiksel olarak anlamlı düzeyde yüksek olduğu saptanmıştır $(\mathrm{p}=0,000)$ (Tablo 3). Hastaların \%54,3'ü haftada iki kere, \%32,1' haftada bir kere banyo yaptığını; \%50,6'sı dişlerini hiç fırçalamadığını, \%43,2'si günde bir kere firçaladı̆̆ını ifade etmiştir.

\subsubsection{Benlik Kavram}

Bireylerin kendini tanımlamaları değerlendirildiğinde, \%49,4'ünün kendini olumsuz özellikleriyle tanımladığ (işe yaramaz, şanssız, değersiz, güçsüz, umutsuz, kontrolünü kaybetmiş... gibi) ve özsaygı düzeylerinin, kendini orta ve olumlu özellikleriyle değerlendirenlere göre istatistiksel olarak anlamlı düzeyde düşük olduğu saptanmıştır $(\mathrm{p}=0,000)$

Bireylerin beğendikleri özellikleri değerlendirildiğinde; \%33,3'ünün beğendiği özellik olmadığı ve \%27,2'sinin kişilik özelliklerini beğendiği bulunmuştur. Kendisiyle ilgili beğendiği özellik olmadığını ifade eden bireylerin özsayg1 düzeyleri en düşük ve fiziksel özelliklerini beğenen $(\% 6,2)$ bireylerin özsayg1 düzeyleri en yüksek bulunmuştur. $\mathrm{Bu}$ farklılık istatistiksel olarak anlamlıdır $(\mathrm{p}=0,043)$ (Tablo 3).

Bireylerin değiştirmek istedikleri özellikleri incelendiğinde; \%44,4'ünün psikiyatrik hastalıklarıyla ilgili özellikleri değiştirmek istediklerini ifade etmişlerdir. Değiştirmek istedikleri özelliğin olmadığını belirten bireylerin özsaygı düzeyleri diğer gruplara göre istatistiksel olarak anlamlı düzeyde daha yüksek bulunmuştur ( $\mathrm{p}=0,001)$ (Tablo 3$)$.
Bireylerin fizyolojik fonksiyon alanı değerlendirildiğinde; \%71,6'sının iştahının normal olduğu, \%56,8'inin beden kitle indeksinin 20-24,9 arasında olduğu, \%4,9'unun idrar inkontinans1, \%7,4'ünün konstipasyon sorunu yaşadiğ 1 , \%56,7'si cinsel yaşamının hastalıktan etkilendiği, \%64,2'sinin uykuya dalma ya da devam ettirmede sorun yaşadığ belirlenmiştir. Uykuyu kesintiye uğratan nedenleri; bireylerin \%44,4'ü (36 hasta) stres, \%28,4'ü (23 hasta) ilaçlar, \%27,22'si diğer nedenler (ağrı, gürültü, yatak değişikliği gibi) olarak belirtmiştir. Ayrıca bireylerin $\% 74,1$ 'i gündüz uyuma alışkanlığı olduğunu ifade etmiştir. Bireylerin \%48, 1'inin yorgunluk düzeyinin 5-10 arasında olduğu ve bu bireylerin özsaygı düzeyinin, 0-4 arasında yorgunluk belirten bireylere göre istatistiksel olarak anlamlı düzeyde düşük olduğu saptanmıştır $(\mathrm{p}=0,012)$ (Tablo 4).

\subsubsection{Manevi Boyut}

Çalışmaya katılan bireylerin yaşamla ilgili inançları değerlendirildiğinde; \%24,7'si olumsuz ("yaşamak güzel değil", "keşke hiç doğmasaydım", "hasta olduğun bir hayat, hayat değildir"....gibi), \%48,1'i orta düzeyde ifadeler kullanmıştır. Ölümle ilgili inançlarına yönelik, bireylerin \%59,3'ü olumlu ifadeler ("yeni bir başlangıç", "kurtuluş", "hayatın gerçeği”, "Allah'a kavuşma"... gibi), \%11,1'i olumsuz ("korkuyorum", "yitip gitmek" "ben zaten ölmüşüm"...gibi) ifadeler kullanmıştır. Yaşam ve ölümle ilgili olumsuz inançlara sahip bireylerin özsaygı düzeyleri diğerlerine göre istatistiksel olarak anlamlı düzeyde daha düşük bulunmuştur ( $\mathrm{p}=0,000 ; \mathrm{p}=0,012)$ (Tablo 4).

3.1.9.Rol ve Ilişkiler

Bu alanda; bireylerin eğitim ve çalışma yaşamları, aile içi ve sosyal ilişkilerinin hastalıktan etkilenme durumu incelenmiștir. Bireylerin \%60,5'inin eğitim yaşantısı, \%92,6'sının çalışma yaşamı, \%97,5'inin aile içi ilişkileri ve $\% 96,3$ 'ünün sosyal ilişkileri psikiyatrik hastalıtan etkilenmiștir. Etkilendiğini ifade eden ve etkilenmediğini ifade eden bireylerin özsaygı düzeyleri arasında istatistiksel olarak anlamlı bir farklılık bulunmamıştır $(p>0,05)$ (Tablo 5). Eğitim yaşantısında "okuldan ayrılma", çalıșma yaşamında "işe devam edememe", aile içi ilişkilerde "rolleri yerine getirememe" ve sosyal ilişkilerde "dışlanma" nedenleri en çok belirtilen etkileyici faktörler olmuştur.

\subsubsection{Basetme}

Bireylerin bu alandaki gereksinimlerine yönelik olarak bireylerin yaşamlarında stres yaratan olayın varlığı, sosyal destek yeterliliği ve kullandıkları başetme yöntemleri incelenmiştir. Bireylerin \%86,4'ü yaşamında stres yaratan bir olay yaşadığını belirtmiştir. Bu olayın ne olduğu sorulduğunda, \%34,6's1 (28 hasta) psikiyatrik hastalığın öğrenilmesinin, \%20,9'unun (17 hasta) bir yakının ani ve beklenmedik ölümünün, \%16,1'inin (13 hasta) ilişki sorunlarının (boşanma, aldatılma, tartışma gibi), \%14,8'inin (12 hasta) diğer nedenlerin (kazalar, maddi kayıp, sağlık sorunları, istismar gibi) yaşamlarında en çok stres yaratan olaylar olduğunu ifade etmişlerdir. 
Tablo 4. Bireylerin Fizyolojik Fonksiyonlar ve Manevi Boyut Alanlarında Bakım Gereksinimlerine Göre Özsaygı Puanları (N=81)

\begin{tabular}{|c|c|c|c|c|}
\hline $\begin{array}{l}\text { BAKIM GEREKSINIIM } \\
\text { ALANLARI }\end{array}$ & $\mathbf{N}$ & $\%$ & $\begin{array}{l}\text { RÖSÖ } \\
\mathbf{X} \pm \text { SD }\end{array}$ & Analiz \\
\hline \multicolumn{5}{|l|}{ FIZYOLOJIKK FONK. } \\
\hline Beslenme & & & & \multirow{4}{*}{$\begin{array}{c}\mathrm{F}=1,242 ; \\
p=0,295\end{array}$} \\
\hline Normal iştah & 58 & 71,6 & $3,44 \pm 2,10$ & \\
\hline Artmış iştah & 4 & 4,9 & $3,50 \pm 2,51$ & \\
\hline Azalmış iştah & 19 & 23,5 & $4,31 \pm 1,97$ & \\
\hline \multicolumn{5}{|l|}{ Beden Kitle Índeksi } \\
\hline 20 den az (zayıf) & 13 & 16 & $4,38 \pm 1,93$ & \multirow{4}{*}{$\begin{array}{l}\mathrm{F}=0,717 \\
p=0,545\end{array}$} \\
\hline 20-24,9 (uygun kilo) & 46 & 56,8 & $3,60 \pm 2,09$ & \\
\hline 25-29,5 (hafif obez) & 14 & 17,3 & $3,35 \pm 2,27$ & \\
\hline $30-39,9$ (obez) & 8 & 9,9 & $3,25 \pm 2,18$ & \\
\hline \multicolumn{5}{|l|}{ Boşaltım (üriner sistem) } \\
\hline Normal & 77 & 95,1 & $3,61 \pm 2,12$ & \multirow{2}{*}{$\begin{array}{l}\mathrm{t}=-0,825 ; \\
p=0,412\end{array}$} \\
\hline İnkontinans & 4 & 4,9 & $4,50 \pm 1,29$ & \\
\hline \multicolumn{5}{|l|}{$\begin{array}{l}\text { Boşaltım (gastrointestinal } \\
\text { sistem) }\end{array}$} \\
\hline Normal & 75 & 92,6 & $3,61 \pm 2,12$ & \multirow{2}{*}{$\begin{array}{c}\mathrm{t}=-0,619 ; \\
p=0,538\end{array}$} \\
\hline Konstipasyon & 6 & 7,4 & $4,16 \pm 1,72$ & \\
\hline \multicolumn{5}{|l|}{ Cinsel Yaşam } \\
\hline Etkilenmedi & 33 & 40,8 & $3,61 \pm 2,14$ & \multirow{3}{*}{$\begin{array}{l}\mathrm{F}=0,919 ; \\
p=0,633\end{array}$} \\
\hline Etkilendi & 46 & 56,7 & $4,36 \pm 1,42$ & \\
\hline Diğer & 2 & 2,5 & $3,87 \pm 1,85$ & \\
\hline \multicolumn{5}{|l|}{ Uyku } \\
\hline $\begin{array}{l}\text { Dalma/devam ettirmede } \\
\text { sorun }\end{array}$ & 52 & 64,2 & $3,76 \pm 2,09$ & \multirow[t]{2}{*}{$\begin{array}{l}\mathrm{t}=0,658 ; \\
p=0,513\end{array}$} \\
\hline Uykuda değişim yok & 29 & 35,8 & $3,44 \pm 2,13$ & \\
\hline \multicolumn{5}{|l|}{ Yorgunluk şiddeti } \\
\hline $0-4$ arası & 42 & 51,9 & $3,09 \pm 2,10$ & \multirow{2}{*}{$\begin{array}{l}\mathrm{t}=-\mathbf{2 , 5 7 4} ; \\
p=0,012\end{array}$} \\
\hline 5-10 aras1 & 39 & 48,1 & $4,25 \pm 1,94$ & \\
\hline \multicolumn{5}{|l|}{ MANEVI BOYUT } \\
\hline Yaşamla ilgili inançlar & & & & \multirow{4}{*}{$\begin{array}{c}\mathrm{F}=12,145 \\
p=0,000\end{array}$} \\
\hline Olumlu & 22 & 27,2 & $3,36 \pm 1,98$ & \\
\hline Olumsuz & 20 & 24,7 & $5,40 \pm 0,88$ & \\
\hline Orta & 39 & 48,1 & $2,92 \pm 2,11$ & \\
\hline \multicolumn{5}{|l|}{ Ölümle ilgili inançlar } \\
\hline Olumlu & 24 & 29,6 & $3,95 \pm 1,92$ & \multirow{3}{*}{$\begin{array}{c}\mathrm{F}=4,722 \\
p=0,012\end{array}$} \\
\hline Olumsuz & 9 & 11,1 & $5,33 \pm 1,00$ & \\
\hline Orta & 48 & 59,3 & $3,18 \pm 2,16$ & \\
\hline
\end{tabular}

RÖSÖ: Rosenberg'in Özsaygı Ölçeği

Sosyal desteğin yeterliliği incelendiğinde;

hastaların \%53,1'i kısmen yeterli, \%23,5'i yetersiz olduğunu ifade etmişlerdir. Başetme yöntemi olarak; bireylerin $\% 64,2$ 'si sigara içme, \%39,5'i yürüyüş/egzersiz yapma, $\% 38,5{ }^{\prime} \mathrm{i}$ dini ritüelleri uygulama, \%29,6'sı ilaç kullanma, \%23,5'i duyguları paylaşma, \%18,5'i ağlama ve \%7,4'ü kitap/dergi okumayı kullandıklarını ifade etmiştir.

Sosyal destek yeterliliği ve ağlama dışındaki diğer başetme yöntemleri açısından bireylerin özsaygı puan ortalamaları arasında istatistiksel olarak anlamlı bir farklılık bulunmamıștır. Ağlama yöntemini kullanan bireylerin özsaygı düzeyleri, kullanmayan bireylere göre istatistiksel olarak anlamlı düzeyde daha düşük bulunmuştur $(p=0,012)$ (Tablo 5).

3.1.11. Özsaygı puanlarını etkileyen değişkenler

Özsaygı puan ortalamaları karşılaştııılmasında anlamlı bulgular elde edilen değişkenler (Tablolar 1,3,4,5) kullanılarak yapılan doğrusal çoklu regresyon analizi sonuçlarına göre $(\mathrm{SE}=1,859, F=7,744, p=0,000)$; bazı değişkenlerin özsayg1 puanları üzerinde anlamlı bir etkiye sahip olduğu bulunmuştur $\left(\mathrm{R}=0,73, \mathrm{R}^{2}=0,53\right.$,
Tablo 5. Bireylerin Rol ve İlişkiler ve Başetme Alanlarında Bakım Gereksinimlerine Göre Özsaygı Puanları (N=81)

\begin{tabular}{|c|c|c|c|c|}
\hline $\begin{array}{l}\text { BAKIM GEREKSINIM } \\
\text { ALANLARI }\end{array}$ & $\mathbf{N}$ & $\%$ & $\begin{array}{l}\text { RÖSÖ } \\
\mathbf{X} \pm \mathbf{S D}\end{array}$ & Analiz \\
\hline \multicolumn{5}{|l|}{ ROL VE ILISŞKILER } \\
\hline \multicolumn{5}{|l|}{ Ĕgitim yaşamında etkilenme } \\
\hline Var & 49 & 60,5 & $3,75 \pm 2,08$ & \multirow{2}{*}{$\begin{array}{l}\mathrm{t}=0,532 ; \\
p=0,596\end{array}$} \\
\hline Yok & 32 & 39,5 & $3,50 \pm 2,14$ & \\
\hline \multicolumn{5}{|l|}{ Çalışma yaşamında etkilenme } \\
\hline Var & 75 & 92,6 & $3,62 \pm 2,11$ & \multirow{2}{*}{$\begin{array}{c}\mathrm{t}=- \\
0,417 ; \\
p=0,678\end{array}$} \\
\hline Yok & 6 & 7,4 & $4,00 \pm 2,09$ & \\
\hline \multicolumn{5}{|l|}{ Aile içi ilişkilerde etkilenme } \\
\hline Var & 79 & 97,5 & $3,67 \pm 2,06$ & \multirow{2}{*}{$\begin{array}{l}\mathrm{t}=0,444 ; \\
p=0,658\end{array}$} \\
\hline Yok & 2 & 2,5 & $3,00 \pm 2,24$ & \\
\hline \multicolumn{5}{|l|}{ Sosyal ilişkilerde etkilenme } \\
\hline Var & 78 & 96,3 & $3,66 \pm 2,08$ & \multirow{2}{*}{$\begin{array}{l}\mathrm{t}=0,268 \\
p=0,768\end{array}$} \\
\hline Yok & 3 & 3,7 & $3,33 \pm 2,05$ & \\
\hline \multicolumn{5}{|l|}{ BAŞETME } \\
\hline \multicolumn{5}{|l|}{ Yaşamında stres yaratan olay } \\
\hline Var & 70 & 86,4 & $3,61 \pm 2,13$ & \multirow{2}{*}{$\begin{array}{c}\mathrm{t}=- \\
0,432 ; \\
p=0,668\end{array}$} \\
\hline Yok & 11 & 13,6 & $3,90 \pm 1,92$ & \\
\hline \multicolumn{5}{|l|}{ Sosyal destek yeterliği } \\
\hline Yetersiz & 19 & 23,5 & $3,31 \pm 2,02$ & \multirow{3}{*}{$\begin{array}{c}\mathrm{F}=0,321 \\
; \\
p=0,727\end{array}$} \\
\hline Kismen & 43 & 53,1 & $3,74 \pm 2,18$ & \\
\hline Yeterli & 19 & 23,5 & $3,78 \pm 2,04$ & \\
\hline \multicolumn{5}{|l|}{ Kullanılan başetme yöntemleri } \\
\hline Ağlama & 15 & 18,5 & $4,86 \pm 1,59$ & \multirow{2}{*}{$\begin{array}{l}\mathrm{t}=2,564 \\
p=0,012\end{array}$} \\
\hline Yok & 66 & 81,5 & $3,37 \pm 2,11$ & \\
\hline \multirow[t]{2}{*}{ Duyguları paylaşma } & 19 & 23,5 & $3,84 \pm 2,01$ & \multirow{2}{*}{$\begin{array}{l}\mathrm{t}=0,444 \\
p=0,659\end{array}$} \\
\hline & 62 & 76,5 & $3,59 \pm 2,12$ & \\
\hline Dinsel ritüelleri uygulama Var & 31 & 38,3 & $3,54 \pm 2,17$ & \multirow{2}{*}{$\begin{array}{c}\mathrm{t}=- \\
0,356 ; \\
p=0,723\end{array}$} \\
\hline Yok & 50 & 61,7 & $3,72 \pm 2,07$ & \\
\hline \multirow[t]{2}{*}{ Kitap/dergi okuma } & 6 & 7,4 & $3,83 \pm 1,83$ & \multirow{2}{*}{$\begin{array}{c}\mathrm{t}=- \\
0,216 ; \\
p=0,830\end{array}$} \\
\hline & 75 & 92,6 & $3,64 \pm 2,12$ & \\
\hline \multirow[t]{2}{*}{ Sigara içme } & 52 & 64,2 & $3,78 \pm 2,11$ & \multirow{2}{*}{$\begin{array}{l}\mathrm{t}=0,768 ; \\
p=0,445\end{array}$} \\
\hline & 29 & 35,8 & $3,41 \pm 2,07$ & \\
\hline \multirow[t]{2}{*}{ İlaç kullanma } & 24 & 29,6 & $3,87 \pm 2,04$ & \multirow{2}{*}{$\begin{array}{l}\mathrm{t}=0,612 ; \\
p=0,542\end{array}$} \\
\hline & 57 & 70,4 & $3,56 \pm 2,14$ & \\
\hline \multirow[t]{2}{*}{ Yürüyüş/egzersiz } & 32 & 39,5 & $3,40 \pm 2,12$ & \multirow{2}{*}{$\begin{array}{c}\mathrm{t}=- \\
0,852 ; \\
p=0,393\end{array}$} \\
\hline & 49 & 60,5 & $3,81 \pm 2,08$ & \\
\hline
\end{tabular}

RÖSÖ: Rosenberg'in Özsaygı Ölçeği

$p=0,000)$. Özsaygı puanları en çok çalışma durumundan etkilenmiştir $(\beta=1,885, p=0,002)$. Ardından sırasıyla genel görünüm $(\beta=1,200, p=0,003)$, yorgunluk şiddeti $(\beta=0,212, p=0,003)$, intihar riski $(\beta=-1,166, p=0,013)$, ve beğenilen yönler $(\beta=0,187, \quad \mathrm{p}=0,024)$ değişkenleri gelmektedir. Ayrıca, bu değişkenler özsaygı puanlarındaki varyansın \%53'ünü açıklamaktadır (Tablo $6)$.

\subsection{Tartışma}

Bu çalıșmada psikiyatri kliniğinde yatarak tedavi gören bireylerin bakım gereksinimleri ve özsayg1 düzeyleri incelendi. Hastaların yaklaşık yarısının özsaygı düzeylerinin düşük olduğu, birçok alanda bakım 
Tablo 6. Özsaygı Puanlarını Öngören Doğrusal Çoklu Regresyon Analizi (N=81).

\begin{tabular}{|l|c|c|c|c|c|c|}
\hline Model & $\boldsymbol{B}$ & $\boldsymbol{\beta}$ & $\boldsymbol{t}$ & $\boldsymbol{p}$ & $\boldsymbol{R}$ & $\boldsymbol{R}^{\mathbf{2}}$ \\
\hline Constant & 0,766 & & & & 0,725 & $\mathbf{0 , 5 2 5}$ \\
\hline $\begin{array}{l}\text { Psikiyatrik } \\
\text { tanı }\end{array}$ & 0,161 & 0,119 & 1,337 & 0,185 & & \\
\hline $\begin{array}{l}\text { Eğitim } \\
\text { durumu }\end{array}$ & $-0,303$ & $-0,134$ & $-1,442$ & 0,154 & & \\
\hline $\begin{array}{l}\text { Çalışma } \\
\text { durumu }\end{array}$ & 1,885 & 0,270 & 3,216 & $\mathbf{0 , 0 0 2}$ & & \\
\hline İntihar riski & $-1,166$ & $-0,217$ & $-2,547$ & $\mathbf{0 , 0 1 3}$ & & \\
\hline $\begin{array}{l}\text { Kendini } \\
\text { tanımlama }\end{array}$ & $-0,072$ & $-0,023$ & $-0,268$ & 0,790 & & \\
\hline $\begin{array}{l}\text { Beğenilen } \\
\text { özellikler }\end{array}$ & 0,187 & 0,217 & 2,303 & $\mathbf{0 , 0 2 4}$ & & \\
\hline $\begin{array}{l}\text { Genel } \\
\text { görünüm }\end{array}$ & 1,200 & 0,280 & 3,057 & $\mathbf{0 , 0 0 3}$ & & \\
\hline $\begin{array}{l}\text { Yorgunluk } \\
\text { şiddeti }\end{array}$ & 0,212 & 0,263 & 3,069 & $\mathbf{0 , 0 0 3}$ & & \\
\hline $\begin{array}{l}\text { Yaşamla } \\
\text { ilgili } \\
\text { inançlar }\end{array}$ & 0,173 & 0,070 & 0,474 & 0,637 & & \\
\hline $\begin{array}{l}\text { Ölümle ilgili } \\
\text { inançlar }\end{array}$ & $-0,667$ & $-0,286$ & $-1,949$ & 0,055 & & \\
\hline & & & & \\
\hline
\end{tabular}

gereksinimlerinin olduğu ve bazı değişkenlerin özsaygı düzeyi için anlamlı belirleyiciler olduğu saptandı.

Araştırma kapsamına alınan bireylerin toplam özsayg düzeyi orta $(3,65 \pm 2,09)$ olup, yaklaşık yarısının $(\% 45,7)$ özsayg1 düzeyi düşük bulundu. Polonya'da [16], Çin'de [17], US'de [18], Güney Kore'de 19] aynı ölçek kullanılarak yapılan çalışmalarda da psikiyatri hastaları özsaygı ölçek ortalamasına yakın puan almışlardır. Bu araştırma bulgusu, diğer çalışmalardaki bulgular ile benzerlik göstermektedir.

Katılımcıların özsaygı puanları demografik özelliklerine göre değerlendirildiğinde; yaş, cinsiyet, medeni durum, ekonomik durum ve kimlerle beraber yaşadığı açısından anlamlı farklılık bulunmadı. Ancak, okuryazar olmayan ve çalışmayan bireylerin özsaygı düzeyleri daha düşük bulundu. Akademik başarı ve çalışma durumu ile özsaygı arasında bir ilişki olmadığını belirten [20] ve çalışan hastaların daha düşük özsaygıya sahip olduğunu [21] belirten çalışmalar bu çalışma bulgusuyla ters düşmektedir. Buna karşın, yapılan bir çalışmada benzer olarak eğitim düzeyi yüksek olan ve geçmişte bir işte çalışan hastaların özsaygı düzeyi anlamlı düzeyde yüksek bulunmuştur [19]. Eğitim düzeyinin yüksek olması iş fırsatlarını artırabilir, bağlantılı olarak bir işte çalışma hastalar için sosyalleşme firsatı ve güven hissi sağlayabilir. Olumlu çalışma deneyimi olan hastaların özsaygılarının bu bağlamda daha yüksek olabileceği düşünülmektedir.

$\mathrm{Bu}$ çalışmada, bireylerin primer psikiyatrik tanılarına göre özsaygıları incelendiğinde; en düşük özsaygı düzeyi depresif bozuklukta görülmekle birlikte ardından anksiyete bozk., madde kullanım bozk., şizofreni ve bipolar bozk. gelmektedir. Yapılan diğer çalışmalar da benzer olarak, özellikle majör depresif bozukluklar, distimik bozukluk, şizofreni, anksiyete bozuklukları, yeme bozuklukları, cinsel işlev bozukluğu ve kişilik bozuklukları olmak üzere birçok psikiyatrik bozuklukta özsaygıda azalma olduğunu belirtmektedir $[8,11,22]$. Düşük özsaygı DSM-V'te birçok psikiyatrik hastalıkla ilişkili veya psikiyatrik hastalık için bir tanı ölçütüdür
[23]. Silverstone ve Salsali (2003)'ne göre düşük özsayg1 psikiyatrik bozuklukların gelişimine yatkınlığ 1 arttırır ve bir psikiyatrik bozukluğun varlığı da özsaygıyı azaltır. Ayrıca çalışmacılar bu etkinin daha çok majör depresyonda belirgin olduğunu belirtmişlerdir [11]. Bu bakış açısıyla çalışma bulguları literatüre uygunluk göstermektedir.

Bireylerin Bakım Gereksinim Alanlarl ve Özsaygl Düzeyleri

Sağlık Yönetimi: Çalışmada, bireylerin yaklaşık yarısının genel sağlığını kötü olarak değerlendirdikleri ve bu bireylerin özsaygı düzeylerinin daha düşük düzeyde olduğu bulundu. Özsaygi bireyin kendisi hakkında ne ölçüde olumlu ya da olumsuz görüşlere sahip olduğu ya da öznel değerlendirmesi ile ilgili olduğu için özsaygısı düşük kişilerin genel sağlık algısının da olumsuz olması olası bir durumdur [24].

Çalışma bulgularına göre; bireylerin \%18,5'inin intihar riski vardı ve bu hastaların özsaygı düzeyleri daha düşüktü. Benzer şekilde, yapılan bir çalışmada intihar girişimi öyküsü olan hastaların özsaygısının daha düşük olduğu bulunmuştur [22]. Rizwan ve Ahmad (2010) psikiyatri hastalarında özsaygının, intihar eğilimlerinin anlamlı bir yordayıcısı olduğunu belirtmişlerdir [25]. Yüksek özsaygı, etkili başa çıkmayı kolaylaştırır ve ruh sağlığı için koruyucu bir faktördür [7]. Bu bakış açısıyla düşük özsaygıya sahip kişilerin sorunlarla etkili baş edememesi ve genel durumlarını kötü olarak algılamaları sonucu intihara daha eğilimli oldukları düşünülebilir. $\mathrm{Bu}$ bağlamda, hemşirelik bakımında intihar riski bulunan hastalarla çalışırken, özsayg1 düzeyinin değerlendirilmesi önem kazanmaktadır.

Kendine Bakım: $\mathrm{Bu}$ alanda bireylerin çoğunluğunun günlük bakımını bağımsız düzeyde yapabildiği, yarısından fazlasının bakımlı göründüğü ve bu bireylerin özsayg1 düzeyinin daha yüksek olduğu bulunmuştur. $\mathrm{Bu}$ çalışma bulgularına benzer olarak; Oh ve ark. (2017) şizofreni hastaları ile yaptıkları çalışmada özsaygının fiziksel faktörler, görünüşe olan ilgi ve beden imajından etkilediğini belirtmişlerdir [19]. Hastaların günlük yaşam aktivitelerini yerine getirme işlevselliği, özbakımın ve görünümün gelişmesini sağlar, böylece beden imaj1 memnuniyeti artar. Bu olumlu gelişmelerin de özsaygıya katk1 sağlayacağ1 düşünülebilir.

Benlik Kavramı: Çalışmamızda, bireylerin yaklaşık yarısı kendini olumsuz özellikleriyle tanımladı ve bu bireylerin özsaygı düzeyleri daha düşük bulundu. Ayrıca, bireylerin çoğunluğu kendileriyle ilgili beğendiği bir özellik olmadığını ve yaklaşık yarısı da hastalıklarıyla ilgili özellikleri değiştirmek istediklerini belirtti. Maslow'un ihtiyaçlar hiyerarşisinde yer alan saygı gereksinimine göre; insanların yüksek özsaygıya sahip olmaları ve bunun diğer kişilerden kendilerine yansıması gerekir. Özsayg1 gereksinimi karşılanırsa bireyler kendinden emin ve değerli; buna karşın özsaygı sarsıldığında, değersiz ve çaresiz hissederler [26]. Bu durum, çalışmamıza katılan bireylerin olumsuz öz değerlendirmeleri ile özsaygılarındaki düşüklük arasındaki ilişkiyi açıklamaktadır. 
Fizyolojik Fonksiyonlar alanında hastaların yarısından fazlasının uyku ve cinsel yaşam alanlarında, bazı hastaların da boşaltım ve beslenme alanlarında sorun yaşadığı belirlendi. Çalışma bulgularına benzer olarak, ruhsal bozukluğu olan hastalarla yapılan çalışmalarda bireylerin fiziksel sağlık alanında karşılanmamış gereksinimlerinin olduğu bulunmuştur [27,28]. Ruhsal hastalıkların doğası, ilaçların yan etkileri gibi faktörler nedeniyle fizyolojik fonksiyon alanlarında gereksinimlerin oluştuğu düşünülebilir. Bu bulgulara ek olarak, kendini yorgun hisseden bireylerin özsaygı düzeyinin daha düşük olduğu bulundu. Bütüncül yaklaşım doğrultusunda bakım verirken, gereksinim alanlarından birindeki aksaklık diğer gereksinim alanları için risk oluşturabilir [26,29]. Bu bulgu, temel fizyolojik gereksinimlerinin karşılanmasında sorun yaşayan bireylerin psikolojik gereksinimleri dâhilinde özsaygısının etkilenebileceği şeklinde açıklanabilir.

Manevi Boyut: Yaşam ve ölümle ilgili olumsuz inançlara sahip bireylerin özsaygı düzeyleri anlamlı ölçüde daha düşük bulunmuştur. Abdel-Khalek (2016)'a göre; özsaygı, hayattaki başarının anahtarıdır. Özsaygısı düşük olan insanların birçok şeye karşı genel bir olumsuz tutum sergileme eğilimi vardır. $\mathrm{Bu}$ kişilerde duyguların dengesiz olması ile umutsuzluk, değersizlik hissi yaşanır ve bu da yaşam doyumunun azalmasına yol açabilir [30]. Yapılan çalışmalarda psikiyatri hastalarında yaşam kalitesinin özsayg1 düzeyleriyle ilişkili olduğu saptanmıştır [31-33]. Bu açıdan değerlendirildiğinde, psikiyatri hastalarının özsaygı düzeyini etkileyen yaşam ve ölüme ilișkin olumsuz inançları, düşünceleri ve bunlara zemin hazırlayan faktörler önemlidir. $\mathrm{Bu}$ alana ilişkin hemşirelik bakımında; yaşamdan anlam bulma, duyguların sözelleştirilmesi, bakış açısını yeniden yapılandırmaya yönelik girişimlerin planlanması etkili olabilir [14].

Rol ve Iliş̧kiler: Çalışmamıza katılan bireylerin yarısından fazlası eğitim yaşantısının ve neredeyse tamamı çalışma yaşamı, aile içi ilişkileri ve sosyal ilişkilerinin psikiyatrik hastalıktan etkilendiğini ve bu alanda sıkıntılar yaşadıklarını belirtti. Taburculuk sonrası erken dönemdeki şizofreni hastalarıyla yapılan bir çalışmada hastaların \%61,3'ünün aile içi rollerin etkilendiği bulunmuştur [4]. Kronik ruhsal bozukluğu olan hastalarla yapılan diğer çalışmalarda benzer olarak sosyal ilişkiler alanında gereksinimlerinin olduğu bulunmuştur $[27,28]$. Çalışmamızda "okuldan ayrılma", "işe devam edememe", "rolleri yerine getirememe" ve "dışlanma" rol ve ilişkileri en çok etkileyen faktörlerdi. Genel olarak rol ve ilişkilerinin hastalıktan etkilendiğini ifade eden bireylerin özsaygı düzeyi daha düșük olmasına rağmen bu farklılık istatistiksel olarak anlamlı değildir. Orth, Erol ve Luciano (2018)'ya göre özsaygı bireylerin değişmez bir özelliği değildir. Okul başarısı, iş yaşamı, aile içi yaşanan olaylar özsaygıda dalgalanmalara neden olabilir [24]. Bu görüşe göre çalışma bulgularını değerlendirdiğimizde, bireylerin eğitim ve çalışma yaşamı, aile ve sosyal ilişki alanlarındaki beceri ve yetenekleriyle ilgili öz değerlendirmeleri özsaygılarını etkileyebilir.
Çalışmadaki katılımcıların ifade ettiği rollerini yerine getirememe ve sosyal yaşamdaki dışlanma bireylerde içselleştirilmiş damgalanmaya neden olabilir ki, yapılan çalışmalar içselleştirilmiş damgalanma ile düşük özsaygı arasındaki ilişkiyi ortaya koymaktadır [22,33-35].

Başetme: Bireylerin 86,4'ü yaşamında stres yaratan bir olay yaşadı̆̆ını, çoğunluğu psikiyatrik hastalığ öğrenmenin yaşamlarındaki en stres yaratan olay olduğunu ve sosyal desteğin kısmen yeterli olduğunu belirtti. Kao ve ark. (2017)'na göre psikiyatrik bir hastalık teşhisinin konması bireyler için genellikle stresli ve rahatsız edici bir deneyimdir ve bu hastalıkların etkileriyle baş etmek zor ve sıklıkla yaşam boyu süren bir süreçtir [36]. Sorunlarla baş edebilmek için kullanılan başetme yöntemleri önemlidir. Bu çalışmada; bireyler başetme yöntemi olarak; sırayla sigara içme, yürüyüş/egzersiz yapma, dini ritüelleri uygulama, ilaç kullanma, duyguları paylaşma, ağlama ve kitap/dergi okumayı kullandıklarını belirtti. Ağlama yöntemini kullanan bireylerin özsaygı düzeyleri anlamlı düzeyde daha düşük bulundu. Çalışma bulgularını destekleyen bir çalışmada; şizofreni hastalarının, psikiyatrik hastalığ 1 olmayan bireylerle karşılaştırıldığında, yardım arama veya aktif problem çözme gibi etkili yaklaşımlardan ziyade olumsuz başetme stilleri kullandıkları ve özsaygılarının düşük olduğu belirtilmiştir [17]. Psikiyatrik hastalıklarda etkili başetme yöntemlerinin kullanılması ve sosyal desteğin artırılmasının, bireylerde yeterli ve değerli olma hissi sağlayarak özsaygının gelişmesine katkı sağlayacağı düşünülmektedir.

\subsection{Araștırmanın Sinırlılıkları}

Çalışmaya dahil edilen bireyler, şizofreni, bipolar bozk., major depresif bozk., anksiyete bozk. ve madde kullanım bozukluğu dahil olmak üzere sadece beş tanı kategorisine giren bir hastanenin psikiyatri kliniğinde yatarak tedavi gören hastalardır. $\mathrm{Bu}$ nedenle sonuçlar tüm psikiyatri hastalarına genellenemez.

\section{Sonuc}

$\mathrm{Bu}$ çalışma psikiyatri kliniğinde yatarak tedavi gören bireylerin birçok alanda bakım gereksinimleri olduğunu ve bazı gereksinim alanlarının bireylerin özsayg1 düzeylerini açıklamada belirleyici olduğunu ortaya koymaktadır. Bulgulara göre; bireylerin sağlık yönetimi, benlik kavramı, kendine bakım, fizyolojik fonksiyonlar, manevi, rol ve ilişkiler ve başetme alanlarında ve alt alanlarında bakım gereksinimlerinin olduğu ve hastaların yaklaşık yarısının özsaygı düzeylerinin düşük olduğu bulunmuştur. Okuryazar olmayan, çalışmayan, tanısı depresif bozukluk olan, sağlığını kötü olarak değerlendiren, intihar riski olan, günlük bakımını yapmada bağımlı olan, bakımsız görünen, kendini olumsuz özelliklerle tanımlayan, kendinde beğendiği özellikleri olmayan, yorgunluk şiddeti daha yüksek olan, yaşam ve ölümle ilgili olumsuz inançlara sahip ve "ağlama" yöntemini kullanan bireylerin özsaygı düzeyleri daha düşük bulunmuştur. Regresyon analizi sonucuna göre; "çalışma durumu, genel görünüm, yorgunluk şiddeti, intihar riski, beğenilen özellikler" 
değişkenleri özsaygı puanlarının anlamlı yordayıcılarıdır.

Psikiyatri hastalarının bakım gereksinimleri, psikiyatri hemşireliğinin temel alanıdır. Kronik ruhsal bozukluğu olan bireylerin gereksinimlerini belirlemek uygun girişimleri planlayabilmek için önemlidir. $\mathrm{Bu}$ konuda yapılan çalışmalar, bakımın iyileştirilmesine katkı sağlayacaktır. $\mathrm{Bu}$ çalışma, bu konuda ileride yapılacak olan çalışmalara veri sağlamaktadır. Gelecekte, özsaygı düzeylerindeki farklılıkların nedenlerine yönelik boylamsal çalışmalar ve nitel yaklaşımla yapılacak araştırmaların yapılması önerilmektedir. Hastaların bakım gereksinimlerinin karşılanması ve özsaygı düzeyinin yükseltilmesine yönelik hemşirelik girişimlerini ve girişimlerin etkisini inceleyen deneysel araştırmaların yararlı olacağı düşünülmektedir. $\mathrm{Bu}$ nedenle, psikiyatri hemşireleri, psikiyatri hastalarının özsaygısına ve özsaygısını etkileyen gereksinim alanlarına katkıda bulunan eğitim ve bakım programları geliştirmelidir.

\section{Referanslar}

1. World Health Organization (WHO). Community mental health services will lessen social exclusion, says WHO; 2007 http://www.who.int/mediacentre/news/notes/2007/np25/en/.(acces sed 13.11.2019)

2. Tuncer, G.Z, Duman, Z.C.. Kronik ruhsal bozukluğu olan bireylerin gereksinimleri: sistematik derleme, needs of individuals with chronic mental disorders: a systematic review, Psikiyatride Güncel Yaklasımlar, 2020, 12(2), 155-167.

3. Zúñiga, A, Navarro, J.B, Lago, P, Olivas, F, Muray, E, Crespo, M, Evaluation of needs among patients with severe mental illness, A community study, Actas Españolas de Psiquiatría, 2013, 41(2), 115-121.

4. Taș S, Buldukoğlu K, Early period self-care ability and care requirements of schizophrenia patients after discharge, Journal of Psychiatric Nursing, 2018, 9(1), 11-22.

5. Zeigler-Hill, V, The connections between self-esteem and psychopathology, Journal of Contemporary Psychotherapy, 2011, 41, 157-164.

6. Rosenberg, M, Rosenberg Self-Esteem Scale (RSE), 1965, 61. http://www.integrativehealthpartners.org/downloads/ACTmeasure s.pdf\#page $=61$, (accessed 10.07.2020)

7. Orth, U, Robins, RW, The development of self-esteem, Current Directions in Psychological Science, 2014, 23(5), 381-387.

8. Rizwan, M, Ahmad, R, Self-Esteem deficits among psychiatric patients, SAGE Open, 2015, 5(2).

9. Link, B.G, Phelan, J.C, Labeling and stigma, In: Aneshensel C.S, Phelan, J.C B.A, ed,Handbook of the Sociology of Mental Health, 2nd ed, Springer, Dordrecht, 2013, 525-541.

10. Sowislo, J.F, Orth, U, Does low self-esteem predict depression and anxiety? A meta-analysis of longitudinal studies, Psychological Bulletin, 2013, 139(1), 213-240.

11. Silverstone, P.H, Salsali, M, Low self-esteem and psychiatric patients: Part I - The relationship between low self-esteem and psychiatric diagnosis, Annals of General Hospital Psychiatry, $2003,2$.

12. Salsali, M, Silverstone, P.H, Low self-esteem and psychiatric patients: Part II - The relationship between self-esteem and demographic factors and psychosocial stressors in psychiatric patients, Annals of General Hospital Psychiatry, 2003, 2, 3.

13. Parker, T.J, Page, A.C, Hooke, G.R, The influence of individual, group, and relative self-esteem on outcome for patients undergoing group cognitive-behavioural therapy treatment, British Journal of Clinical Psychology, 2013, 52(4), 450-463.

14. Carpenito-Moyet, L, Hemşirelik tanıları el kitabı, (FE, ed.), İstanbul, Nobel Tip Kitabevleri, 2015.

15. Çuhadaroğlu, F, Adolesanlarda benlik saygısı. Yayınlanmamıs uzmanlık tezi, Hacettepe Üniversitesi, Ankara, 1986, 70-75.
16. S̈witaj, P, Grygiel, P, Anczewska, M, Wciórka, J, Experiences of discrimination and the feelings of loneliness in people with psychotic disorders: The mediating effects of self-esteem and support seeking, Comprehensive Psychiatry, 2015, 59, 73-79.

17. Xu, Z.Y, Zu, S, Xiang, Y.T, et al, Associations of self-esteem, dysfunctional beliefs and coping style with depression in patients with schizophrenia: A preliminary survey, Psychiatry Research, 2013, 209(3), 340-345.

18. Lysaker, P.H, Davis, L.W, Tsai, J, Suspiciousness and low selfesteem as predictors of misattributions of anger in schizophrenia spectrum disorders, Psychiatry Research, 2009, 166(2-3), 125-131.

19. Oh, E.J, Song, E.J, Shin, J.E, Individual factors affecting selfesteem, and relationships among self-esteem, body mass index, and body image in patients with schizophrenia, Archives of Psychiatric Nursing, 2017, 31(6), 588-595.

20. Hacioglu Yildirim, M, Alantar, Z, Yildirim, E.A, The relationship between working status and symptoms, quality of life and selfesteem in patients with schizophrenia in Turkey, International Journal of Social Psychiatry, 2014, 60(7), 646-655.

21. Kumar, S, Mohanty, S. Factors associated with self-esteem in patients with chronic schizophrenia, SIS Journal of Projective Psychology and Mental Health, 2016, 23, 56-60.

22. Kök, H, Demir, S, Sizofreni ve bipolar bozukluğu olan hastalarda içselleştirilmiş damgalanma, benlik saygısı ve algılanan sosyal destek, Cukurova Medical Journal, 2017, 43(1), 1-1.

23. Amerikan Psikiyatri Birliği (APA). Ruhsal bozuklukların tanısal ve sayımsal elkitabı, Beşinci Baskı (DSM-5), Tanı Ölçütleri Başvuru Elkitabı, 5th ed, (Köroğlu E, ed.), Ankara, Hekimler Yayın Birliği, 2013.

24. Orth, U, Erol, R.Y, Luciano, E.C, Development of self-esteem from age 4 to 94 Years: A meta-analysis of longitudinal studies, Psychological Bulletin, 2018, 144(10), 1045-80.

25. Rizwan, M, Ahmad, R, Self-esteem as a predictor of suicide risk among psychiatric patients, Journal of Alternative Perspectives in the Social Sciences, 2010, 2(2), 577-592.

26. Varcarolis, E, Halter, M.J, Varcarolis' foundations of psychiatric mental health nursing: a clinical approach, 7th ed, Missouri: Elsevier Saunders, 2014.

27. Bitter, N.A, Roeg, D.P.K, van Nieuwenhuizen. C, van Weeghel. J, Identifying profiles of service users in housing services and exploring their quality of life and care needs, BMC Psychiatry, 2016, 16(1), 419

28. Cialkowska-Kuzminska, M, Misiak, B, Kiejna, A, Patients' and carers' perception of needs in a Polish sample, The International journal of social psychiatry, 2014, 60(2), 178-184.

29. Townsend, M.C, Morgan, K.I, Promoting self-esteem. In Townsend, M.C, Morgan, K.I, eds, Psychiatric mental health nursing: concepts of care in evidence-based practice, 9th ed., Philadelphia, FA Davis Company, 2017, 266-277.

30. Abdel-Khalek, A.M, Introduction to the psychology of self-esteem, In, Franklin Holloway, ed., self-esteem perspectives, influences and improvement strategies, New York, Nova Science Publishers, Inc., 2016, 1-17.

31. Świtaj, P, Grygiel, P, Chrostek, A, Nowak, I, Wciórka, J, Anczewska, M, The relationship between internalized stigma and quality of life among people with mental illness: are self-esteem and sense of coherence sequential mediators? Quality of Life Research, 2017, 26(9), 2471-2478.

32. Mashiach-Eizenberg, M, Hasson-Ohayon, I, Yanos, P.T, Lysaker P.H, Roe, D. Internalized stigma and quality of life among persons with severe mental illness: The mediating roles of self-esteem and hope, Psychiatry Research, 2013, 208(1), 15-20.

33. Kim, E.Y, Jang, M.H, The Mediating effects of self-esteem and resilience on the relationship between internalized stigma and quality of life in people with schizophreniai Asian Nursing Research, 2019, 13(4), 257-263.

34. Maharjan, S, Panthee, B, Prevalence of self-stigma and its association with self-esteem among psychiatric patients in a Nepalese teaching hospital, A cross-sectional study, $B M C$ Psychiatry, 2019, 19(1), 347.

35. Picco, L, Pang, S, Lau, Y.W, et al., Internalized stigma among psychiatric outpatients: Associations with quality of life, functioning, hope and self-esteem, Psychiatry Research, 2016, 246, 500-506.

36. Kao, Y-C, Lien, Y-J, Chang, H-A, Tzeng, N-S, Yeh, C-B, Loh, C$\mathrm{H}$, Stigma resistance in stable schizophrenia: the relative 
contributions of stereotype endorsement, self-reflection, selfesteem, and coping styles, The Canadian Journal of Psychiatry / La Revue Canadienne de Psychiatrie, 2017, 62(10), 735-744.

http://edergi.cbu.edu.tr/ojs/index.php/cbusbed isimli yazarın CBU-SBED başlıklı eseri bu Creative Commons Alıntı-Gayriticari4.0 Uluslararası Lisans1 ile lisanslanmıştır.

(c) (i) \&) 